\title{
REMAINS OF THE PROTOZOAN STICHOLONCHE ZANCLEA IN THE FAECAL PELLETS OF Paracalanus quasimodo, Parvocalanus crassirostris, Temora stylifera AND Temora turbinata (COPEPODA, CALANOIDA) IN BRAZILIAN COASTAL WATERS
}

\author{
Eneida Eskinazi Sant'Anna* \\ Universidade Federal de Ouro Preto \\ Laboratório de Ecologia Aquática - UFOP.ICEB.DEBIO \\ (Campus Morro do Cruzeiro, s/n, 35400-000 Ouro Preto, MG, Brasil) \\ *Corresponding author: eskinazi@iceb.ufop.br
}

Descriptors: Copepods, Faecal pellets, Feeding, Protozoa, Brazil.

Descritores: Copépodos, Pelotas fecais, Alimentação, Protozoário, Brasil.

\begin{abstract}
Studies of copepod feeding have identified these organisms as key species in marine ecosystems, because they have a pivotal position in food webs: they control primary production through grazing, and are also a crucial link between the microbial food web and higher trophic levels, especially because they are able to predate on protozoa (STOECKER; CAPUZZO, 1990). The ingestion of protozoans has attracted particular attention, not only because it extends our understanding of the manifold energy pathways that structure aquatic food webs, but also because it involves an important behavioral aspect, i.e., what strategies are used to locate and capture preferred prey (ÁZEMAR et al., 2007). Copepods of the genera Paracalanus and Temora are believed to devote most of their time to filter feeding (VAN DUREN; VIDELER, 1995). The feeding habits of the copepods Paracalanus quasimodo, Temora stylifera and $T$. turbinata have shown that these species are omnivorous, but primarily opportunistic herbivores and that carnivory is infrequent (TURNER, 1984a, 1984b).
\end{abstract}

Paracalanus quasimodo, Parvocalanus crassirostris, Temora stylifera and T. turbinata are abundant in Brazilian coastal waters, and are assumed to play a fundamental role in the control of primary production. Scanning electron microscopy analysis of the faecal pellets of these copepods was performed to assess the main food item ingested during the occurrence of different water masses in the São Sebastião Channel (SSC), a coastal ecosystem located on the northeast coast of São Paulo State. Sampling was carried out every three months in the SSC, from January 1996 to July 1997 and also in July 1998 and January 1999, at two sampling points (map available in Eskinazi-Sant'Anna; Björnberg, 2006). Surface (0.5 $\mathrm{m})$ water samples $(250 \mathrm{ml})$ for phytoplankton and protozooplankton analyses were taken with a Van Dorn bottle $(5 \mathrm{~L})$ and preserved in Lugol's solution.
Phytoplankton was enumerated using the inverted microscope method and carbon content determined using the volume:carbon conversions.

Mesozooplankton was collected during 2min surface tows with a $150-\mathrm{mm}$ mesh net. Adult females of the copepods Parvocalanus crassirostris, Paracalanus quasimodo, Temora stylifera and Temora turbinata were sorted under a WILD M8 stereomicroscope, isolated within 20 min of collection, and transferred to Petri dishes containing collected surface sea water, and then left for 30 to $120 \mathrm{~min}$ to produce faecal pellets. The expelled faecal pellets (38 from $P$. crassirostris, 78 from $P$. quasimodo, 37 from $T$. stylifera and 21 from $T$. turbinata) were individually removed by pipette and placed in petri dishes containing a mixture of filtered sea water (Nuclepore cellulose acetate membrane filters $20 \mathrm{~mm}$ ) and $10 \mathrm{~mm}$ screened surface sea water. The pellets were then left for $24 \mathrm{~h}$ at $24^{\circ} \mathrm{C}\left( \pm 2^{\circ} \mathrm{C}\right)$ for microbial stripping of their peritrophic membranes. All pellets were subsequently preserved in $4 \%$ formalin-seawaterglutaraldehyde solution. Ashore, preserved pellets were individually removed by pipette, transferred to Nuclepore filters, and then left to adhere. Filters with attached pellets were washed in distilled water for salt elimination, dehydrated in a graded ethanol series (50, $60,70,80,90,95$, and $100 \%$ ), left to dry at room temperature, and then coated with gold. The faecal pellets were examined with a Zeiss DSM-950 Scanning Electron Microscope (SEM).

Analysis of the faecal pellets of Paracalanus quasimodo, Parvocalanus crassirostris, Temora stylifera and Temora turbinata indicated the presence of the protozoan $S$. zanclea fragments and remains of diatoms, mainly Chaetoceros sp., Thalassiotrix frauenfeldii, Skeletonema costatum and Thalassionema nitzschioides. Identification of $S$. zanclea fragments was only possible under SEM, which revealed their characteristic ornamentation, 
consisting of a series of fringes along the spine (Fig. $2 \mathrm{~A}$ and B). Fragments of $S$. zanclea were abundant in the faecal pellets of $P$. quasimodo. In some pellets, these fragments were the only food item found, which reinforces the indications of selective capture of this protozoan (Fig. 1). Besides $S$. zanclea remains, fragments of diatoms (Chaetoceros sp., Skeletonema costatum, Thalassionema nitzschioides and Thalassiotrix frauenfeldii) were also observed (Fig. 2E). Analysis of $P$. crassirostris faecal pellets showed, besides phytoplankton items, the presence of remains of $S$. zanclea (Fig. 2C), suggestive of selective feeding, because of the large size of the protozoan $(>200 \mu \mathrm{m})$ and the small size of $P$. crassirostris individuals $(<0.6$ $\mathrm{mm})$. Unidentified centric and pennate nanoplanktonic cells $(<20 \mathrm{~mm})$ were observed in the faecal pellets of all the species, especially $P$. crassirostris, illustrating the importance of these copepods to the energy pathway in the nano-trophic food web compartment (Fig. 2D).

Faecal pellets of Temora stylifera contained a wide variety of food remains, including diatoms, dinoflagellates, silicoflagellates, radiolarians and amorphous material, in addition to $S$. zanclea remains (Fig. 2F and G). Remains of S. zanclea were also common in the faecal pellets of T. turbinata. (Fig. 2G and $\mathrm{H}$ ).
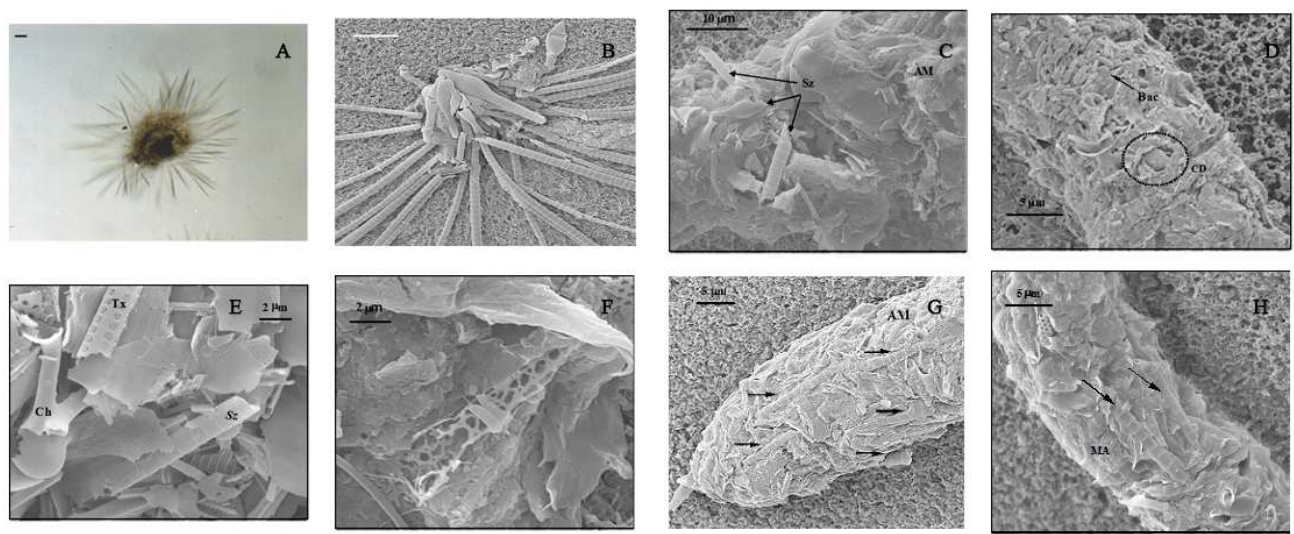

Fig. 2. Optical (A) and scanning electron microscopy (B) of Sticholonche zanclea (taken from ESKINAZISANT'ANNA, 2006) and contents of fecal pellets from the copepods of São Sebastião Channel; C and D: Parvocalanus crassirostris $-(\mathbf{C}-\mathrm{P} 2 \mathrm{Jan} / 96-\mathrm{Bac}=$ Bacteria; $\mathrm{CD}=$ Centric Diatom; $\mathbf{D}-\mathrm{P} 2$ Oct/96- Sz $=$ Sticholonche zanclea $; \mathrm{AM}=$ Amorphous material). E: Paracalanus quasimodo $-\left(\mathrm{P} 2 \_\mathrm{Jan} / 98-\mathrm{Ch}=\right.$ Chaetoceros $\mathrm{sp}$; $\mathrm{Tx}=$ Thalassio thrix frauenfeldii; $\mathrm{Sz}=$ Sticholonche zanclea $). \mathbf{F}$ and $\mathbf{G}:$ Temora stylifera $-\left(\mathbf{F}-\mathrm{P} 1 \_\mathrm{Jan} / 99-\right.$ Radiolarian remains; $\mathbf{G}-\mathrm{P} 1 \_J a n / 99-$ S. zanclea remains). H: T. turbinata $-\left(\mathrm{P} 2 \_J a n / 97-\mathrm{Sz}=\right.$ Sticholonche zanclea remains). 
There is little published information on predation on protozoans under natural conditions. Evidence of the ingestion of protozoans comes, mostly, from predation experiments done in situ or in the laboratory (SÁNCHEZ, 2011), through the use of biomarkers (LI et al., 1996), filming (VERITY; PAFFENHÖFER, 1996), or through identification of hard parts such as loricae and skeletal material in gut contents or in faecal pellets (CONOVER, 1982). In tropical coastal waters, the trophic model linking copepods and primary production is the classical representation of the regional marine food web. In fact, tropical copepods are considered "small-sized" species (in general, $<2 \mathrm{~mm}$ ) and the occurrence of predation on large-sized components of the protozoan communities is not considered a regular trophic pathway, since the algal resource is abundant yearround and the size spectrum of the phytoplankton is diverse and appropriate for filter-feeding copepod species $(\sim 20$ and $100 \mu \mathrm{m})$. Because phytoplankton is available in the SSC (phytoplankton density and biomass and protozooplankton abundance data are available in Eskinazi-Sant'Anna; Björnberg, 2006), questions that arise are: why is $S$. zanclea predated on by copepods, including small copepods such as Parvocalanus crassirostris and at high frequency? Also, what would be the competitive advantage for the active capture of a species that is relatively large (> $200 \mathrm{~mm}$ ) and rare in the environment? Copepods can switch their feeding modes depending on algal resources available, requirements for micronutrients and competition pressure. The search for additional food sources can also occur when phytoplankton biomass falls to very low levels, or when drastic changes in phytoplankton composition occur (COWLES et al., 1988).

The SSC is dominated by Coastal Water $\left(\mathrm{CW}: \mathrm{T}>20^{\circ} \mathrm{C} ; \mathrm{S}>36 \%\right.$ ), but during spring and summer a distinct flow of nutrient-rich, high-salinity, low-temperature water (South Atlantic Central Water, SACW: $\mathrm{T}<20^{\circ} \mathrm{C} ; \mathrm{S}>35 \%$ ) can be detected in the deepest layers. The $\mathrm{CW}$ is superficial, with oligotrophic characteristics, marked by the supremacy of flagellates (GIANESELLA-GALV ÃO et al., 1999) and enriched seasonally by intrusion of the SACW. Diatoms need high nutrient concentrations, and for this reason are scarce in oligotrophic waters. Because diatoms are the main food item ingested by calanoid copepods (KÖSTER et al., 2011), the quantitative dominance of flagellates in the SSC waters, may be the determining factor for incorporation of heterotrophic food sources. Utilization of varied food sources may also be associated with specific micronutrient requirements, which would help maintain the nutritional status of individuals. In addition, a large-sized species may be selected because it is easily detectable and offers an important energy source. Protozoans are richer in proteins and lipids than diatoms, which may be why they are targets of such intense predation.

Parvocalanus crassirostris, Paracalanus quasimodo, Temora stylifera and Temora turbinata are perennial species in the SSC. The apparent ability to switch between two feeding modes might be selectively advantageous in environments with great variations in prey size and abundance, which is typical of coastal waters. In addition, the results underline the role of protozooplankton to structure food webs in oligotrophic tropical coastal waters. The next step to comprehend this trophic link between calanoid copepods and the protozoan $S$. zanclea is to carry out experimental situations considering different types of food particles (diatoms) versus $S$. zanclea abundance. These experiments could be fundamental to understand why this protozoan is the target of such intense predation in Brazilian coastal waters.

\section{ACKNOWLEDGEMENTS}

The author is grateful to the Center of Marine Biology (CEBIMar) of the University of São Paulo, and the Center of Electronic Microscopy (CEMEL) of the Federal University of Minas Gerais for the use of their facilities. I would also thank Dr. Tagea Kristina Simon Bjornberg for her advice and Dr. Janet Reid for the revision of the English text. Financial support was provided by FAPESP (Fundação de Amparo à Pesquisa do Estado de São Paulo).

\section{REFERENCES}

AZÉMAR, F.; BOULÊTREAU, S.; LIONARD, M.; MUYLAERT, K.; VYVERMAN, W.; MEIRE, P.; TACKX, M. Looking for general trends in trophic interactions among estuarine micro- and mesozooplankton. J. Plankton Res., v. 29, p. 1135$1147,2007$.

CONOVER, R. J. Interrelations between microzooplankton and other plankton organisms. Annals Inst. Oceanog. Paris, v. 59, p. 31-46, 1982.

COWLES, T. J.; OLSON, R.; CHISHOLM, S. W. Food selection by copepods: discrimination on the basis of food quality. Mar. Biol., v. 100, p. 41-49, 1988.

ESKINAZI-SANT'ANNA, E. M. Sticholonche zanclea (Protozoa, Actinopoda), in fecal pellets of copepods and Euphasia sp. in Brazilian coastal waters. Braz. J. Biol., v. 66, p. 839-847, 2006.

ESKINAZI-SANT'ANNA, E. M.; BJÖRNBERG, T. K. S. Seasonal dynamics of mesozooplankton in Brazilian coastal waters. Hydrobiologia, v. 563, p. 253-268, 2006.

GIANESELLA-GALVÃO, S. M. F.; KUTNER, M. B. B.; SALDANHA-CORRÊA, F. M. P.; POMPEU, M. Assessment of plankton community and environmental conditions in São Sebastião Channel prior to the construction of a produced water outfall. Rev. Bras. Oceanog.,v. 47, p. 29-46, 1999. 
KÖTER, M.; STIEMANN, R.; MEUCHE, A. PAFFENHÖFER, G. A. The ultrastructure of a doliolid and a copepod fecal pellet. J. Plankton Res., v. 33, p. 1538-1549, 2011.

LI, A.; COATS, D. W.; ADAM, E. J. Ingestion of fluorescently labeled and phycoerythrin-containing prey by mixotrophic dinoflagellates. Aquat. Microb. Ecol., v. 10, p. 139-147, 1996.

SÁNCHEZ, N.; GONZÁLEZ, H.E.; IRIARTE, J.L. Trophic interactions of pelagic crustaceans in Comau Fjord (Chile): their role in the food web. J. Plankton Res., v. 33, p. 1212-1229, 2011.

STOECKER, D. K.; CAPUZZO, J. M. Predation on protozoa: its importance to zooplankton. J. Plankton Res., v. 12, p. 891-908, 1990.

TURNER, J. T. Zooplankton feeding ecology: contents of fecal pellets of the copepods Eucalanus pileatus and Paracalanus quasimodo from continental shelf waters of the Gulf of Mexico. Mar. Ecol. Prog. Ser., v. 15, p. 27 $46,1984 \mathrm{a}$.
TURNER, J. T. Zooplankton feeding ecology: contents of fecal pellets of the copepods Temora turbinata and $T$. stylifera from continental shelf and slope waters near the mouth of the Mississippi River. Mar. Biol., v. 82, p. 73$83,1984 b$.

VAN DUREN, L; VIDELER, J. Swimming behavior of developmental stages of the calanoid copepod Temora longicornis at different food concentrations. Mar. Ecol. Prog. Ser., v. 126, p. 153-161, 1995.

VERITY, P. G.; PAFFENHÖFER, G. A. On assessment of prey ingestion by copepods. J. Plankton Res., v. 18, p. 1767-1779, 1996.

(Manuscript received 06 August 2012; revised 16 February 2013; accepted 05 March 2013) 